\title{
Effect of compatibility of mixed parent pairs on heightening productivity of pigs
}

\author{
V. Pelyh, \\ Corresponding Member of the National Academy of Sciences of Ukraine, Doctor of Agricultural \\ Sciences
}

S. Ushakova

State Higher Educational Institution "Kherson State Agrarian University"

The purpose. To assess productive qualities of pigs and to determine effect of compatibility of mixed parent pairs. Methods. Practical standards of assessment of productivity of pigs. Effect of compatibility based on I.P. Sheiko's procedure. Results. It is fixed that the least width of fat $(15,75 \mathrm{~mm})$ and the greatest area of "muscle eye» $(42,65 \mathrm{~cm})$ has pigs of combination $+(\mathrm{Vb} \times \mathrm{L}) \times \times \hat{\delta}(\mathrm{P} \times \mathrm{D})$. The greatest effect of compatibility was in bunch $q(\mathrm{Vb} \times \mathrm{L}) \times{ }^{\lambda}(\mathrm{D} \times \mathrm{P})(138,87 \%)$. Conclusions. According to feeding attributes and indexes of index assessment pigs of genotype $+(\mathrm{Vb} \times \mathrm{L}) \times \hat{\gamma}(\mathrm{D} \times \mathrm{P})$ were selected. According to slaughter qualities the best were animals from group $q(\mathrm{Vb} \times \mathrm{L}) \times \hat{\delta}(\mathrm{P} \times \mathrm{D})$.

Key words: feeding and meat qualities, level and effect of compatibility.

Improving the competitiveness of pork production on the domestic market requires a transition to a more intensive level of pig breeding, which necessitates the use of specialized meat breeds of pigs that provide the maximum effect in purebred breeding, crossbreeding and hybridization with further selection for a higher proportion of meat in the carcass. This is caused by an increasing demand for lean pork and reduced energy consumption for producing a meaty carcass compared to a fatty one [2].

In order to enhance high quality pork production, researchers study different variants of crossbreeding and hybridization with the maximum use of highly productive meat breeds of pigs $[3,4,5,7,9,10]$.

Therefore, the task of our research was to examine the world's best genotypes of pigs imported to Ukraine with the purpose of obtaining competitive high quality pork.

Research aim. Evaluating the fattening and meat traits of pigs and determining the compatibility effect of cross parental pairs.

Materials and methods of research. The research was conducted under the conditions of Freedom Farm Bacon LLC, Kherson region. We used the thoroughbred pigs 9 LWxơ LW (control) and cross animals of two variants of crossbreeding: $\%(L W x L) \times 0^{x}(D x P \%)$ and $q(L W x L) \times o^{x}(P x D)$.

To estimate fattening traits, the experiment included 150 pigs; slaughter traits were assessed for 12 animals.

Fattening and meat-fat traits were evaluated according to conventional methods [8]. The index of fattening traits was calculated by the following formula $[1,8]$ :

$$
\mathrm{I}=\frac{\mathrm{A}^{2}}{B \cdot C}
$$

where $A-$ gross gain for the period of fattening, $\mathrm{kg}$;

$B$ - number of days of fattening.

$\mathrm{C}-$ feed consumption per $1 \mathrm{~kg}$ of gain, feed units.

To assess the fattening and meat traits of pigs, we used the index of meat and fattening traits (IMFT) by the method of I.P. Sheiko, M.O. Loban, and others [6].

$\operatorname{IMFT}_{0}=1,24\left(192-\mathrm{X}_{1}\right)+0,1\left(\mathrm{X}_{2}-733\right)+78\left(3,52-\mathrm{X}_{3}\right)+2,1\left(\mathrm{X}_{4}-97,4\right)+3,2\left(26,7-\mathrm{X}_{5}\right)+10\left(\mathrm{X}_{6}-11,1\right)$ where $X 1$ - average age of achieving a live weight of $100 \mathrm{~kg}$, days;

$\mathrm{X} 2$ - average daily gain, $\mathrm{g}$; 
$\mathrm{X} 3$-feed consumption per $1 \mathrm{~kg}$ of gain, feed units;

$\mathrm{X} 4$-carcass length, $\mathrm{cm}$;

$\mathrm{X} 5$ - pork fat thickness, $\mathrm{mm}$;

$\mathrm{X} 6$ - weight of the posterior third of half carcass, $\mathrm{kg}$.

According to the IMFTo values obtained, we calculated the IMFT mean value and the compatibility level of each parental pair $(C L)$ in points by the formula:

$\mathrm{CL}=\mathrm{IMFT}_{0}-\mathrm{IMFT}_{n}$

For parental pairs with a positive CL value we determined the compatibility effect (CE) by the formula:

$\mathrm{C} E=\left(\frac{\mathrm{MFT} 0}{\mathrm{IMFT}_{n}}\right) \cdot 100$

We estimated the compatibility of parental pairs of pigs as the best under the highest CE.

Research results. The $q(\mathrm{LWXL}) \times \widehat{ }(\mathrm{DxP})$ group of pigs showed better fattening traits compared to the control group of animals and the $(\mathrm{LWxL}) \times \mathrm{O}^{\mathrm{r}}(\mathrm{PxD})$ combination by the age of achieving a live weight of $100 \mathrm{~kg}-+16,52$ days $(\mathrm{P}<0.001)$ and $+3,78$ days; by average daily gain during fattening $-+84,79 \mathrm{~g}$ $(\mathrm{P}<0.001)$ and $+19,47 \mathrm{~g}$, respectively (Table 1$)$.

Table 1. Fattening traits of young pigs

\begin{tabular}{|c|c|c|c|}
\hline Parameters & $+\mathbf{L W} \mathbf{x} \mathrm{O}^{\lambda} \mathrm{LW}$ & $q(L W x L) \times \delta^{\wedge}(D x P)$ & $\rho(\mathrm{LWxL}) \mathrm{x}^{\AA}(\mathrm{PxD})$ \\
\hline $\begin{array}{l}\text { Age of achieving a live } \\
\text { weight of } 100 \mathrm{~kg} \text {, days }\end{array}$ & $185,46 \pm 1,14$ & $168,94 \pm 1,03^{* * *}$ & $172,72 \pm 1,27^{* * *}$ \\
\hline Average daily gain, $g$ & $720,38 \pm 5,45$ & $805,14 \pm 6,46^{* * *}$ & $785,67 \pm 5,24^{\star * *}$ \\
\hline $\begin{array}{l}\text { Feed consumption per } 1 \mathrm{~kg} \\
\text { of gain, feed units }\end{array}$ & $3,57 \pm 0,02$ & $3,33 \pm 0,02^{* * *}$ & $3,38 \pm 0,01^{* * *}$ \\
\hline $\begin{array}{l}\text { Index of fattening traits, } \\
\text { points }\end{array}$ & $14,07 \pm 0,28$ & $19,50 \pm 0,39^{* * *}$ & $18,44 \pm 0,37^{* * *}$ \\
\hline
\end{tabular}

Note: ${ }^{*} \mathrm{P}<0,05 ;{ }^{* *}-\mathrm{P}<0,01,{ }^{* * *}-\mathrm{P}<0,001$

The studies have shown that the lowest feed consumption per unit of gain was in the $q(L W x L) x 0^{x}(D x P)$ group of pigs, which is less than the values for purebred animals by $-0,24$ feed units $(P<0,001)$ and for the $P(L W x L) \times o^{r}(P x D)$ genotype by $-0,05$ feed units.

The index assessment of fattening traits was made taking into account gross gain, fattening period and feed consumption in the study period. The highest value of the index was observed in the

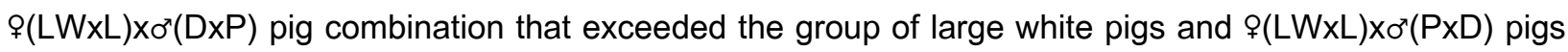
by 5,4 points $(P<0,001)$ and 1,06 points, respectively.

Thus, the use of DxP cross boars combined with LWXL sows gives us grounds to confirm the effectiveness of using this parental form. These animals reached slaughter condition faster, had higher average daily gains and were characterized by the lowest feed consumption per $1 \mathrm{~kg}$ of gain during fattening.

The results of the control slaughter of pigs indicate the highest slaughter yield in the $9(L W x L) x 0^{\prime}(D x P)$ $(73,77 \%)$ group of pigs that exceeded the control group of large white pigs by $+3,60 \%$, and the

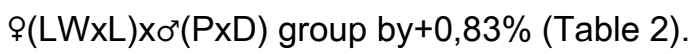


Table 2. Slaughter traits of pigs

\begin{tabular}{|l|l|l|l|}
\hline Parameters & $L W \times o^{*} \mathrm{LW}$ & $q(\mathrm{LWxL}) \times 0^{*}(\mathrm{DxP})$ & $q(\mathrm{LWxL}) \times 0^{*}(\mathrm{PxD})$ \\
\hline Slaughter yield, \% & 70,17 & 73,77 & 72,94 \\
\hline $\begin{array}{l}\text { Thickness of pork fat over 6-7 } \\
\text { thoracic vertebrae, mm }\end{array}$ & $22,25 \pm 2,29$ & $16,00 \pm 0,71^{*}$ & $15,75 \pm 0,85^{*}$ \\
\hline Loin eye area, cm & $31,40 \pm 0,90$ & $42,05 \pm 1,14^{* * *}$ & $42,65 \pm 1,42^{\star * *}$ \\
\hline Carcass length, cm & $99,75 \pm 2,17$ & $99,50 \pm 1,04$ & $97,25 \pm 1,11$ \\
\hline $\begin{array}{l}\text { Weight of the posterior third of } \\
\text { half carcass, kg. }\end{array}$ & $11,55 \pm 0,48$ & $12,90 \pm 0,25^{*}$ & $13,35 \pm 0,55^{*}$ \\
\hline
\end{tabular}

Note: ${ }^{*}-\mathrm{P}<0,05 ;{ }^{* *}-\mathrm{P}<0,01,{ }^{* * *}-\mathrm{P}<0,001$

Pigs of the $P(L W x L) \times \sigma^{x}(P x D)$ group exceeded purebred animals and animals of the $P(L W x L) \times \sigma^{x}(D x P)$ genotype in the loin eye area by $+11,25 \mathrm{~cm}^{2}(P<0,001)$ and $+0,6 \mathrm{~cm}^{2}$, respectively, and by the mass of the posterior third of half carcass by $+1,80 \mathrm{~kg}(P<0,05)$ and $+0,45 \mathrm{~kg}$. We have determined the lowest thickness of pork fat in pigs of the $P(L W x L) \times 0^{\prime}(P x D)$ combination $(15,75 \mathrm{~mm})$, which was significantly lower than in the control group (by $-6,5 \mathrm{~mm}$ ) and in the $9(\mathrm{LWxL}) \times \mathrm{x}^{\mathrm{r}}(\mathrm{DxP})$ combination (by $-0,25 \mathrm{~mm}$ ). The carcass length of pigs of the large white breed was $+0,25 \mathrm{~cm}$ more than in the $9(\mathrm{LWxL}) \times \mathrm{o}^{\mathrm{x}}(\mathrm{DxP})$ group, and $+2,25 \mathrm{~cm}$ more than in the $\$(L W x L) \times 0^{\top}(P x D)$ group.

The study has assessed the compatibility of parental pairs of pigs based on the fattening and meat performance of the offspring. We found the best combinations, which allowed obtaining the heterosis effect (Table 3).

Table 3. Integrated assessment of fattening and meat traits of pigs

\begin{tabular}{|c|c|c|c|}
\hline Parameters & QLWxớLW & $q(L W x L) x \sigma^{x}(D x P)$ & $q(L W x L) x \sigma^{x}(P x D)$ \\
\hline IMFT,points & $39,81 \pm 17,72$ & $95,93 \pm 11,67^{*}$ & $71,49 \pm 7,50$ \\
\hline $\begin{array}{l}\text { Compatibility level CL, } \\
\text { points }\end{array}$ & $-29,26 \pm 17,72$ & $+26,85 \pm 11,67^{*}$ & $+2,41 \pm 7,50$ \\
\hline Compatibility effect CE, \% & $102,03 \pm 0,74$ & $138,87 \pm 16,89$ & $119,55 \pm 12,17$ \\
\hline
\end{tabular}

Note: ${ }^{*}-\mathrm{P}<0,05 ;{ }^{* *}-\mathrm{P}<0,01,{ }^{* * *}-\mathrm{P}<0,001$

The IMFT value for animals of the $9(\mathrm{LWxL}) \times 0^{-}(\mathrm{DxP})$ crossing variant was 95,93 points, which is significantly higher (by $+56,12$ points) than in purebred pigs of the control group $(39,81$ points) and + 24,44 points more than in the $9(\operatorname{LWxL}) \times \sigma^{2}(P \times D)$ group of pigs. Among all the combinations, the highest average compatibility level and compatibility effect were in the $\%(\mathrm{LWxL}) \times \mathrm{x}^{\mathrm{r}}(\mathrm{DxP})$ group $(+26,85$ points and $138,87 \%$, respectively).

The research results showed that 8 out of 12 parental pairs had a positive compatibility level, while 4 pairs had a negative level. The compatibility effect ranged from $101,3 \%$ to $174,1 \%$. By their compatibility, four pairs in $\rho(L W x L) x{ }^{\dagger}(D x P)$ pigs, two pairs from the $q(L W x L) x{ }^{\lambda}(P x D)$ group, and two pairs from the qLWx $\mathrm{L} \mathrm{LW}$ variant had a positive level. 


\section{Conclusions.}

Thus, the best combination for the realization of the heterosis effect was $q(\mathrm{LWxL}) \times{ }^{\lambda}(\mathrm{DxP})$. This is confirmed by the estimates of fattening and meat traits of the offspring and the compatibility effect of parental pairs.

\section{Bibliography}

1. Berezovskij M.D. Efektivnist vidgodivli svinej zarubizhnoi selekcii do drugih vagovih kondicij/M.D. Berezovskij, I.V. Hatko//Naukovo-virobnichij bjuleten «Selekcija». — K., 1997. — №4. — S. 105-107.

2. Voloshhuk V.M. Vidgodivelni, zabijni ta mjasni jakosti pidsvinkiv mjasnih porid/V. M. Voloshhuk, A.P. Vasiliv//Svinarstvo. - 2013. - Vip. 62. - S.8-13

3. Grishina L. P. Efektivnist vikoristannja specializovanogo tipu svinej za shreshhuvannja ta gibridizacii/L. P. Grishina, O. G. Fesenko//Visnik agrarnoi nauki Prichornomorija. - 2015. - Vip. 2(2). - S. 40-47

4. Kodak T. Zabijni jakosti vidgodivelnogo molodnjaku, oderzhanogo vid riznih poednan/T. Kodak, V. Vovk//Tvarinnictvo Ukraini. - 2014. - №7. - S. 18-20.

5. Onishhenko A. O. Porivnjalne vivchennja vidgodivelnih ta mjasnih jakostej svinej riznih genotipiv/A. O. Onishhenko//Visnik agrarnoi nauki Prichornomor'ja. - 2006. - № 3. (35) - S.103.

6. Pat. BY 17677 Respublika Belarus, MPK A 01K 67/02 (2006.01). Sposob ocenki sochetaemosti roditelskih par svinej po mjaso-otkormochnym kachestvam potomkov/Shejko I.P., Loban N.A., Vasiljuk O.Ja., Malikov I.S.; zajavitel i patentoobladatel: Respublikanskoe unitarnoe predprijatie «Nauchnoprakticheskij centr Nacional'noj akademii nauk Belarusi po zhivotnovodstvu». - № a.s. 20100713; zajavl. 11.05.10; opubl. 30.10.13.

7. Susol R. L. Produktivni jakosti svinej suchasnih genotipiv zarubizhnoï selekciï za riznih metodiv rozvedennja $v$ umovah Odeskogo regionu/R. L. Susol//Visnik Sumskogo nacionalnogo agrarnogo universitetu. Serija: Tvarinnictvo. - 2014. - Vip. 2(2). - S. 92-98.

8. Suchasni metodiki doslidzhen u svinarstvi/ Institut svinarstva im. O.V. Kvasnitskogo UAAN za redakcieju V.P. Ribalko M.D.Berezovskogo. - Poltava, 2005. - 227 s.

9. Tomin E.F. Vidgodivelni jakosti svinej velikoi biloi porodi za riznih metodiv rozvedennja/E.F. Tomin//Visnik agrarnoi nauki. - 2007. - № 10. - S. 80-82.

10. Anon, J. Crossbreeding programs for commercial pork production/J. Anon//Washington Agr. ext. Bull. - 1983. - Vol. 1232. - P. 1 - 6. 